\title{
Effect of Tillage and Residue Retention on Soil Properties and Crop Yields in Wheat-Mungbean-Rice Crop Rotation under Subtropical Humid Climate
}

\author{
Nazmus Salahin', Khairul Alam ${ }^{1,2}{ }^{*}$, Abu Taher Mohammad Anwarul Islam Mondol', \\ Mahammad Shariful Islam³, Md. Harunur Rashid', Muhammad Azizal Hoque ${ }^{4}$ \\ ${ }^{1}$ Soil Science Division, Bangladesh Agricultural Research Institute (BARI), Gazipur, Bangladesh \\ ${ }^{2}$ Land Management Group, School of Veterinary and Life Sciences, Murdoch University, Murdoch, Australia \\ ${ }^{3}$ On-Farm Research Division, BARI, Gazipur, Bangladesh \\ ${ }^{4}$ Department of Agricultural Extension, MoA, Dhaka, Bangladesh \\ Email: ^khairul.krishi@gmail.com
}

How to cite this paper: Salahin, N., Alam, K., Mondol, A.T.M.A.I., Islam, M.S., Rashid, Md.H. and Hoque, M.A. (2017) Effect of Tillage and Residue Retention on Soil Properties and Crop Yields in Wheat-MungbeanRice Crop Rotation under Subtropical Humid Climate. Open Journal of Soil Science, 7, 1-17.

http://dx.doi.org/10.4236/ojss.2017.71001

Received: December 2, 2016

Accepted: January 10, 2017

Published: January 13, 2017

Copyright $\odot 2017$ by authors and Scientific Research Publishing Inc. This work is licensed under the Creative Commons Attribution International License (CC BY 4.0).

http://creativecommons.org/licenses/by/4.0/

\begin{abstract}
The effects of conservation agriculture (CA) practices on soil properties along with crop yields of rice-based triple cropping systems have not been adequately assessed in Bangladesh. An experiment was conducted at Bangladesh Agricultural Research Institute, Gazipur, Bangladesh from 2009 to 2012 to assess the effects of tillage practices and crop residue retention on soil physical properties, soil organic carbon (SOC) and crop yields in a wheat-mungbeanrice system. Treatments consisted of three tillage practices (MT: minimum tillage; CT: conventional tillage and DT: deep tillage) and eight levels of crop residue management $\left(S_{0}-\right.$ no residues retention, $S_{r}-$ retention of $30 \mathrm{~cm}$ rice straw, $\mathrm{S}_{\mathrm{m}}$-whole mungbean stover retention, $\mathrm{S}_{\mathrm{w}}-30 \mathrm{~cm}$ wheat straw retention, $\mathrm{S}_{\mathrm{mr}}$-whole mungbean stover \& $30 \mathrm{~cm}$ rice straw retention, $\mathrm{S}_{\mathrm{rw}}-30 \mathrm{~cm}$ rice \& wheat straw retention, $\mathrm{S}_{\mathrm{mw}}$-whole mungbean stover \& $30 \mathrm{~cm}$ wheat straw retention and $S_{w r m}-30 \mathrm{~cm}$ wheat and rice straw along with whole mungbean stover retention) were applied in split plot design with three replications. Bulk density (BD) and porosity responded positively to MT and increased residue retention of all crops $(p>0.05)$. Minimum tillage and $S_{w r m}$ also significantly accumulated SOC ( $<<0.05 ; 0.38 \%$ higher than DT with no residue retention) and retained soil moisture $(\mathrm{p}<0.05)$. Minimum tillage practice performed better in upland crops $(\mathrm{p}<0.05$; wheat $\&$ mungbean yields) and CT outperformed MT in wetland rice crop $(\mathrm{p}<0.05)$. The grain and straw yields of wheat and rice were also influenced by previous crop residue retentions $(\mathrm{p}<0.05)$. The results, therefore, suggested that increased residue
\end{abstract}


retention with minimum tillage practices improved soil properties and yield of upland crops but with deeper tillage practices consistently maintained wetland rice production.

\section{Keywords}

Cropping System, Residue Retention, Soil Moisture, Soil Organic Carbon (SOC), Tillage Practices

\section{Introduction}

Tillage has both advantageous and unfavorable effects on soil physico-chemical properties and on climate change [1]. Extensive tillage practices may lead to breakdown of soil organic matter (SOM) [2] and undesirable change in soil physical properties [3]. The SOM influences soil quality, especially in subsistence agriculture [4] and its proper management is the nucleus of sustainable agriculture [5]. Bangladesh is situated under sub-tropical humid zone and its climate is congenial for rapid decomposition of OM [6]. Average cropping intensity (the ratio of the effective crop area harvested to the physical area) in Bangladesh is $191 \%$ and growing, but cropping patterns are mainly intensive rice-based [6] that promotes high levels of nutrient extraction from soils without allowing time for natural recovery [2]. The use of excessive synthetic fertilizers exacerbates the debilitated soil fertility situation [7]. Moreover, maximum farmers remove crop residues from the land for fuel and fodder [8]. Therefore, SOM depletion is a main cause of low productivity, which is considered one of the most serious threats to the sustainability of Bangladesh agriculture [9]. But scientists suggest ways of increasing SOM in soils. As for example, Singh and Sidhu [10] reviewed 93 papers and concluded that since crop residue in cropping systems like ricewheat contains significant quantities of plant nutrients, their continuous application will have positive effect on $\mathrm{C}$ stock build-up, soil health improvement and fertilizer management in the systems. Yadav and Verma [11] also reported that crop residue addition conserved SOC in the soil. Again Conceição et al. [12] and Bayer et al., [13] reported that the long-term input of different types of crop residues in soils managed under minimum tillage associated with crop rotation increase the C pools. In addition, Kushwaha et al. [14] found that minimum tillage (MT) practices under the principles of conservation agriculture (CA) can reverse the declining trend in soil quality. Hence, CA practices such as minimal soil disturbance, crop residue retention with proper crop rotations could be a good option for Bangladesh to maintain soil health for better crop production [2]. Though the benefits of SOC sequestration to sustaining crop productivity by following minimum disturbance of soil [2] [15] along with applying organic amendments and crop residues and including leguminous crops in the cropping systems have been well documented in other parts of South and Southeast Asia [10] [11] [14], very few studies have been conducted in the rice based triple cro- 
pping systems of Bangladesh of subtropical humid climate in this regard.

The wheat-mungbean-rice is the most promising cropping system in Bangladesh [16], well adopted by the farmers and may provide a huge amount of crop residues per year which are the source of organic carbon in soil [17]. On the other hand, CA is poorly developed for intensive rice based cropping system which is common in Bangladesh. There is a challenge to practice CA for all crops including rice. What is, for that reason, the optimum combination of tillage practices and crop residue retention levels for higher crop yield and soil health? However, the effects of tillage practices and crop residue retention on soil physical properties, SOC content along with crop yields under wheat-mungbean-rice cropping system have not been adequately assessed in Bangladesh [2]. Therefore, the present study was undertaken to assess the effects of tillage practices and crop residue retention on soil physical properties, SOC content and crop yields under wheat-mungbean-rice cropping system.

\section{Material and methods}

\subsection{Description of Experimental Site and Climatic Variables}

The experiment was conducted at the Soil Science Research Station of Bangladesh Agricultural Research Institute (BARI), Gazipur, Bangladesh during 20092010, 2010-2011 and 2011-2012. The study area was in the centre of Modhupur Tract (the agro-ecological zone-28) at about 23.988 north Latitude and 90.408 east Longitude. The experiment site has clay loam soil textural class at $0-15$ and 16 - $30 \mathrm{~cm}$ soil depths having bulk density and particle density of 1.54 and $2.52 \mathrm{~g}$ $\mathrm{cm}^{-3}$, while the porosity was $39 \%$. The soil was slightly acidic (pH-6.6) and low in organic carbon (OC; $0.61 \%)$ and total $\mathrm{N}(\mathrm{TN} ; 0.046 \%)$ in the surface soil, whereas OC $(0.38 \%)$ and TN $(0.32 \%)$ were much lower in the lower layer of soil. Weather data of the experimental period including solar radiation $\left(\mathrm{MJ} \mathrm{m}^{-2} \cdot \mathrm{day}^{-1}\right)$, mean daily Tmax and Tmin $\left({ }^{\circ} \mathrm{C}\right)$, cumulative rainfall of the month $(\mathrm{mm})$ and mean daily reference evapotranspiration (ETo; $\mathrm{mm}$ ) are also presented in the Table 1. The solar radiation remains high during March April and May and afterwards starts decreasing until January in a year. The area receives the highest rainfall in July (318 mm), while the rainfall was high in May, June, August, September as well. The daily minimum and maximum temperatures were highest in June and January. The highest mean daily reference ETo was recorded 5.61 $\mathrm{mm} \cdot \mathrm{day}^{-1}$ in April, while the lowest recorded $2.68 \mathrm{~mm} \cdot \mathrm{day}^{-1}$ in January of the study year.

\subsection{Treatments and Design}

Three types of tillage practices and eight levels of crop residues were tested in a split plot design with three replications where the tillage practices were allocated to main plot and crop residue retentions were in sub-plot. Based on the practices adopted by farmers due to machinery availabilities (as for example, country plough and power tiller which can till up to $10-12 \mathrm{~cm}$ depth and chisel plough which can till soil up to $20-25 \mathrm{~cm}$ depth, the following three tillage practices 
Table 1. Several climatic variables as recorded in the experimental area (average of three years).

\begin{tabular}{cccccc}
\hline \multirow{2}{*}{$\begin{array}{c}\text { Variables/ } \\
\begin{array}{c}\text { Month of the } \\
\text { year }\end{array}\end{array}$} & $\begin{array}{c}\text { Solar Radiation } \\
\left(\mathrm{MJ} \cdot \mathrm{m}^{-2}\right)\end{array}$ & $\begin{array}{c}\text { Precipitation } \\
\text { Cumulative } \\
\text { rainfall }(\mathrm{mm})\end{array}$ & $\begin{array}{c}\text { Mean daily } \\
(\mathrm{Tmax})\end{array}$ & $\begin{array}{c}\text { Mean daily } \\
(\text { Tmin })\end{array}$ & $\begin{array}{c}\text { Mean daily reference } \\
(\mathrm{ETo})\left(\mathrm{mm} \cdot \text { day }^{-1}\right)\end{array}$ \\
\hline November & 15.41 & 25.6 & 29.6 & 21.5 & 3.27 \\
December & 12.52 & 4.0 & 26.7 & 16.7 & 2.81 \\
January & 12.85 & 8.4 & 25.6 & 14.8 & 2.68 \\
February & 17.33 & 20.0 & 28.5 & 17.8 & 3.49 \\
March & 18.67 & 29.8 & 30.1 & 22.0 & 4.93 \\
April & 22.08 & 34.2 & 32.3 & 25.6 & 5.61 \\
May & 20.85 & 245.0 & 32.6 & 26.2 & 5.20 \\
June & 17.44 & 176.0 & 33.4 & 26.7 & 4.33 \\
July & 16.27 & 318.0 & 31.4 & 27.3 & 4.15 \\
August & 15.38 & 275.7 & 31.5 & 26.7 & 3.86 \\
September & 15.01 & 147.2 & 32.1 & 25.6 & 4.14 \\
October & 15.92 & 84.9 & 32.0 & 24.7 & 4.01 \\
\hline
\end{tabular}

were selected. The types of tillage practices were: MT (minimum tillage, single slit was opened with a furrow opener upto $4 \mathrm{~cm}$ soil depth), CT (conventional tillage, where depth was up to $10-12 \mathrm{~cm}$ ) and DT (deep tillage, where depthwas up to $20-22 \mathrm{~cm}$ ). Eight levels of crop residue management were: $S_{0}-$ no crop residues retention, $S_{\mathrm{r}}-$ retention of $30 \mathrm{~cm}$ rice straw, $\mathrm{S}_{\mathrm{m}}$-retention of whole mungbean stover, $S_{\mathrm{W}}$-retention of $30 \mathrm{~cm}$ wheat straw, $\mathrm{S}_{\mathrm{mr}}$-retention of whole mungbean stover \& $30 \mathrm{~cm}$ rice straw), $\mathrm{S}_{\mathrm{rw}}-$ retention of $30 \mathrm{~cm}$ rice \& wheat straw), $\mathrm{S}_{\mathrm{mw}}-$ retention of whole mungbean stover \& $30 \mathrm{~cm}$ wheat straw) and $\mathrm{S}_{\mathrm{wrm}}-$ retention of $30 \mathrm{~cm}$ wheat and rice straw along with whole mungbean stover.

\subsection{Fertilizer Dose and Application Method}

Fertilizer rate for wheat was $120 \mathrm{~kg} \mathrm{~N}, 80 \mathrm{~kg}$ P, $75 \mathrm{~kg} \mathrm{~K}, 15 \mathrm{~kg} \mathrm{~S}, 2 \mathrm{~kg} \mathrm{Zn}$ and $2 \mathrm{~kg}$ $\mathrm{B}$; for mungbean was only $\mathrm{N}_{20}$ and for rice was $90 \mathrm{~kg} \mathrm{~N}, 18 \mathrm{~kg} \mathrm{P}, 48 \mathrm{~kg} \mathrm{~K}$, and 7.5 $\mathrm{kg}$ S/ha. The sources of N, P, K, S, Zn and B were urea, triple super phosphate (TSP), muriate of potash (MoP), gypsum, zinc sulphate and boric acid, respectively. For wheat, all $\mathrm{P}, \mathrm{K}, \mathrm{S}, \mathrm{Zn}$ and half of $\mathrm{N}$ were applied at the time of final land preparation and the remaining half of $\mathrm{N}$ was applied before booting stage. For mungbean, only $20 \mathrm{~kg} / \mathrm{ha} \mathrm{N}$ was applied in all the plots at final land preparation.

In rice, the whole amount of TSP, MoP, Gypsum, $\mathrm{ZnSO}_{4}$ were applied during final land preparation but the urea was applied in three splits; one third of urea was added at 14 days after transplanting and one third was applied at maximum vegetative growth stage ( 35 days after transplanting) and the rest of the urea was applied before panicle initiation stage of the crop ( 55 days after transplanting). 


\subsection{Land Preparation, Seed Sowing/Transplanting and Harvesting}

In MT (tilled at $0-4 \mathrm{~cm}$ depth), seeds were placed at almost $2 \mathrm{~cm}$ depth just by making a very shallow furrow with furrow opener. The conventional tillage (CT, $10-12 \mathrm{~cm}$ depth) was maintained by a power tiller followed by two times laddering with rotavator, whereas the deep tillage (DT, $20-22 \mathrm{~cm}$ depth)was maintained by a chisel plough and later laddering was done for three times by rotavator. The unit plot size was $6 \mathrm{~m} \times 36 \mathrm{~m}$, subplot was $6 \mathrm{~m} \times 4.5 \mathrm{~m}$, the border area from plot to plot was $0.5 \mathrm{~m}$. Accordingly, the total area of the experiment was $2163 \mathrm{~m}^{2}$.

The experiment was started with wheat crop (cv. Sourav, Triticum aestivum L.) sowing in line with spacing $20 \mathrm{~cm}$ (row to row) $\times 5 \mathrm{~cm}$ (plant to plant) on 25 , 28 \& 30 November of 2009 \& 2010, 2011; mungbean (Vigna radiata L.; cv. BARI mung 5) was broadcasted by hands on 10, 10 \& 12 April of 2010, 2011 and 2012, whereas the 30 days-old seedlings of rice (Oryza sativa L.; cv. BRRI dhan 39) was transplanted on 3, 3 \& 5 July of 2010, 2011 and 2012, respectively at $25 \mathrm{~cm}$ apart from rows maintaining $15 \mathrm{~cm}$ hill to hill distance and 3 seedlings per hill. After two times picking from first to third week of June, the total biomass of mungbean was incorporated into soil.

Wheat was harvested in first week of April; mungbean pod was collected from first to third week of June whilst rice was harvested in the second week of November at full maturity in all the three cropping years. During harvesting, the wheat and rice straw at the rate of $30 \mathrm{~cm}$ was retained in the plot but in case of mungbean, whole amount of stover was retained over three years.

\subsection{Intercultural Operations}

Necessary gap filling in case of rice was done at 8 days after transplanting (DAT), whereas thinning of wheat seedlings were done at 18 days after sowing (DAS). The operations such as weeding, insecticide spraying were done as per requirement. Soil moisture monitoring was done throughout the growing season, before irrigation and after crop harvest. Irrigations were done three times for wheat at 21, 45 \& 65 DAS, while no irrigation was scheduled for mungbean and four times supplemental irrigation was applied for rice at 15, 28, 55 \& 75 DAT, respectively. Surface irrigation (borders) was followed for the water supply for all crops of the cropping systems. Irrigation water was applied on the basis of soil moisture status and for wheat, the amount of irrigation water was 38, 45 and 57 $\mathrm{mm}$ at $1^{\text {st }}, 2^{\text {nd }}$ and $3^{\text {rd }}$ times, respectively, whereas for rice, during irrigation, almost $40 \mathrm{~mm}$ water was applied each time.

\subsection{Data Collection}

For data collection of wheat, mungbean and rice, three $1 \mathrm{~m}^{2}$ areas was selected by quadrates after sowing/transplanting at each sub-plot from where all the necessary grain and residue/stover data were taken during the growing period and after harvest. The crops were cut at the ground level and threshing, cleaning and 
drying of grain were performed. The weights of grain and straw were recorded from the three $1 \mathrm{~m}^{2}$ areas of the sub-plot. After threshing, cleaning, and drying of grain (oven dried at $60^{\circ} \mathrm{C}$ for 24 hours), finally data were converted into $t / h a$. In every year, after harvesting every crop, the residue retention data were also collected from the three $1 \mathrm{~m}^{2}$ areas by cutting at the ground. The residues were then oven-dried at $60^{\circ} \mathrm{C}$ and weighed as per residue retention treatments in the study.

\subsection{Soil Sampling and Analysis}

Soil samples at $0-15$ and $16-30 \mathrm{~cm}$ depths were collected from each plot during set-up of the experiment and at the end of three cropping cycles which ended with T. aman rice harvest and kept in standard plastic container and air dried before physico-chemical analysis. At maturity, straw and grain samples were collected for chemical analysis. Then the soil and plant samples were analyzed in the laboratory following standard methods. Soil $\mathrm{pH}$ was measured by a combined glass calomel electrode [18], SOM by wet oxidation method [19], total N by modified Kjeldahl method [20]. Particle size distribution was analyzed by hydrometer method [21]. Bulk density and particle density of the soil were determined by core sampler and pycnometer method, respectively [22]. The soil porosity was computed from the relationship between bulk density (BD) and particle density (PD) using the Equation (1). Soil moisture content was measured following gravimetric method [23].

$$
\operatorname{Porosity}(\%)=(1-\mathrm{BD} / \mathrm{PD}) \times 100
$$

\subsection{Statistical Analysis}

Analysis of variance (ANOVA) for soil parameters and crop yields were done using ANOVA test and the mean values were compared by DMRT (Duncan's Multiple Range Test) method [24].

\section{Results}

\subsection{Effects of Tillage Practice, Crop Residue Retention on Physical Properties of Soil}

The BD, PD and porosity did not vary due to different tillage practices $(\mathrm{p}>0.05)$ after three cropping cycles. The $\mathrm{BD}, \mathrm{PD}$ and porosity ranged from 1.39 to 1.44 $\mathrm{g} / \mathrm{cm}^{3}, 2.43$ to $2.50 \mathrm{~g} / \mathrm{cm}^{3}$ and $42.40 \%$ to $42.80 \%$ of which the highest BD and PD were found in $\mathrm{MT}$ and the lowest in DT, the largest porosity in DT and the lowest in MT (Table 2).

The soil physical properties remained unchanged due to previous crop residue retention after three cropping cycles $(p>0.05)$ under the wheat-mungbean-rice cropping system as data is shown in Table 3. However, the lowest BD (1.38 $\mathrm{g} / \mathrm{cm}^{3}$ ) was found in $S_{w r m}$ where all the three crop residues were retained followed by $\mathrm{S}_{\mathrm{mw}}\left(1.40 \mathrm{~g} / \mathrm{cm}^{3}\right)$ and $\mathrm{S}_{\mathrm{mr}}\left(1.40 \mathrm{~g} / \mathrm{cm}^{3}\right)$ where two crop residues were retained. The highest $\mathrm{BD}\left(1.44 \mathrm{~g} / \mathrm{cm}^{3}\right)$ was recorded in $\mathrm{S}_{0}$ where no crop residue 
Table 2. Effects of tillage practices on soil physical properties after 3-cropping cycles.

\begin{tabular}{cccc}
\hline Treatment & Bulk density $\left(\mathrm{g} / \mathrm{cm}^{3}\right)$ & Particle density $\left(\mathrm{g} / \mathrm{cm}^{3}\right)$ & Porosity (\%) \\
\hline MT & 1.43 & 2.50 & 42.40 \\
CT & 1.40 & 2.44 & 42.62 \\
DT & 1.39 & 2.43 & 42.80 \\
SE ( \pm ) & 0.01 & 0.012 & 0.50 \\
CV (\%) & 1.52 & 2.46 & 3.41 \\
Probability & NS & NS & NS \\
\hline
\end{tabular}

Means followed by common letter are not significantly different at $5 \%$ level by DMRT. Notes: MT-Minimum tillage, CT-Conventional tillage, DT-Deep tillage, SE-Standard error, CV-Co-efficient of variance; NS-Not significant.

Table 3. Effects of previous crop residue retention on soil physical properties after 3-cropping cycles.

\begin{tabular}{cccc}
\hline Treatment & Bulk density $\left(\mathrm{g} / \mathrm{cm}^{3}\right)$ & Particle density $\left(\mathrm{g} / \mathrm{cm}^{3}\right)$ & Porosity $(\%)$ \\
\hline So & 1.44 & 2.49 & 42.17 \\
Sr & 1.43 & 2.48 & 42.34 \\
Sm & 1.42 & 2.47 & 42.51 \\
SW & 1.42 & 2.48 & 42.74 \\
Smr & 1.40 & 2.44 & 42.62 \\
Srw & 1.41 & 2.45 & 42.45 \\
Smw & 1.40 & 2.45 & 42.86 \\
Swrm & 1.38 & 2.43 & 43.21 \\
SE $( \pm)$ & 0.011 & 0.009 & 0.44 \\
CV $(\%)$ & 1.52 & 2.46 & 3.41 \\
Probability & $\mathrm{NS}$ & $\mathrm{NS}$ & $\mathrm{NS}$ \\
\hline
\end{tabular}

Means followed by common letter in the same column are not significantly different at $5 \%$ level by DMRT. Notes: $\mathrm{S}_{0}-$ no crop residues retention, $\mathrm{S}_{\mathrm{r}}$-retention of $30 \mathrm{~cm}$ rice straw, $\mathrm{S}_{\mathrm{m}}-$ retention of whole mungbeanstover, $S_{w}-$ retention of $30 \mathrm{~cm}$ wheat straw, $S_{m r}-$ retention of whole mungbeanstover \& $30 \mathrm{~cm}$ rice straw, $\mathrm{S}_{\mathrm{rw}}-$ retention of $30 \mathrm{~cm}$ rice \& wheat straw), $\mathrm{S}_{\mathrm{mw}}-$ retention of whole mungbeanstover $\& 30 \mathrm{~cm}$ wheat straw and $S_{w r m}$-retention of $30 \mathrm{~cm}$ wheat and rice straw along with whole mungbeanstover, SEStandard error, CV-Co-efficient of variance; NS-Not significant.

was retained (Table 3 ). Like $\mathrm{BD}, \mathrm{PD}$ and soil porosity were also invariably ( $\mathrm{p}>$ 0.05 ) changed due to crop residue retention (Table 3 ). The highest $43.2 \%$ porosity was recorded in $S_{\text {wrm }}$ where all the three crop residues were retained and the lowest $42.2 \%$ was in $\mathrm{S}_{0}$ where no crop residue was retained.

\subsection{Effects of Tillage Practices and Crop Residue Retention on SOC Content}

Soil organic carbon was influenced $(\mathrm{p}<0.05)$ by the interaction effect of tillage practices and crop residue management (Table 4). The significantly highest SOC content $(0.87 \%)$ was found in MT and three crop residues retention combina- 
Table 4. Effects of tillage practices, crop residue retention and their interactions on the SOC content after three cropping cycles.

\begin{tabular}{|c|c|c|c|c|}
\hline \multirow{3}{*}{ Residue } & \multicolumn{4}{|c|}{ SOC (\%) } \\
\hline & \multicolumn{3}{|c|}{ Tillage } & \multirow{2}{*}{ Mean } \\
\hline & MT & $\mathrm{CT}$ & DT & \\
\hline $\mathrm{S}_{0}$ & 0.64 & 0.60 & 0.48 & 0.57 \\
\hline $\mathrm{S}_{\mathrm{r}}$ & 0.75 & 0.71 & 0.57 & 0.68 \\
\hline $\mathrm{S}_{\mathrm{m}}$ & 0.76 & 0.72 & 0.61 & 0.70 \\
\hline $\mathrm{S}_{\mathrm{W}}$ & 0.74 & 0.71 & 0.60 & 0.68 \\
\hline$S_{m r}$ & 0.84 & 0.78 & 0.65 & 0.76 \\
\hline $\mathrm{S}_{\mathrm{rw}}$ & 0.81 & 0.76 & 0.64 & 0.74 \\
\hline $\mathrm{S}_{\mathrm{mw}}$ & 0.84 & 0.80 & 0.70 & 0.78 \\
\hline $\mathrm{S}_{\mathrm{wrm}}$ & 0.86 & 0.82 & 0.72 & 0.80 \\
\hline Mean & 0.78 & 0.74 & 0.62 & - \\
\hline $\mathrm{SE}( \pm)$ & \multicolumn{4}{|c|}{ Tillage $(\mathrm{T})=0.05$, Residue $(\mathrm{R})=0.009$ and $\mathrm{T} \times \mathrm{R}=0.05$} \\
\hline $\mathrm{CV}(\%)$ & \multicolumn{4}{|c|}{2.59} \\
\hline Probability & \multicolumn{4}{|c|}{ Tillage $(\mathrm{T})=\mathrm{NS}$, Residue $(\mathrm{R})=* *$ and $\mathrm{T} \times \mathrm{R}=\mathrm{NS}$} \\
\hline
\end{tabular}

Means followed by common letter in the same column are not significantly different at $5 \%$ level by DMRT. Notes: $S_{0}-$ no crop residues retention, $S_{r}-$ retention of $30 \mathrm{~cm}$ rice straw, $S_{m}-$ retention of whole mungbeanstover, $S_{\mathrm{w}}-$ retention of $30 \mathrm{~cm}$ wheat straw, $S_{\mathrm{mr}}-$ retention of whole mungbeanstover \& $30 \mathrm{~cm}$ rice straw, $\mathrm{S}_{\mathrm{rw}}-$ retention of $30 \mathrm{~cm}$ rice \& wheat straw), $\mathrm{S}_{\mathrm{mw}}-$ retention of whole mungbeanstover \& $30 \mathrm{~cm}$ wheat straw and $\mathrm{S}_{\mathrm{wrm}}-$ retention of $30 \mathrm{~cm}$ wheat and rice straw along with whole mungbeanstover, $\mathrm{SE}-$ Standard error, CV-Co-efficient of variance; NS-Not significant, ${ }^{* *}$-Significant at $1 \%$ probability level.

tion $\left(\mathrm{MT} \times \mathrm{S}_{\mathrm{wrm}}\right)$ which was statistically different from all other treatment combinations $(\mathrm{p}<0.05)$, whereas the lowest $0.44 \%$ SOC content was obtained in combined treatment of DT with no crop residues retention $\left(\mathrm{DT} \times \mathrm{S}_{0}\right)$. The increase of SOC might be due to slow decomposition of high amount of residue retained on soil under minimum tillage.

\subsection{Effects of Tillage Practices and Crop Residue Retention on the Soil Moisture}

Soil moisture content was measured at wheat sowing day, before irrigation at 18 , 55 and 75 DAS and just after the harvest during second rabi season (one of the three crop growing seasons, stretches from November to April) in 2011-2012. The soil moisture measured at $0-15 \mathrm{~cm}$ depth insignificantly changed $(\mathrm{p}>0.05)$ due to different tillage practices and decreased gradually over the time (Table 5) before a medium rainfall occurred which caused increase in soil moisture at harvest time. However, the MT practice gave the highest soil moisture content in all sampling dates from initial to harvest compared to other tillage practices, whereas the lowest moisture was found in DT practice. This was might be owing to, after three cropping year, much more OM accumulated under MT which started conserving more soil moisture. 
Table 5. Effect of tillage practices and residue retention on soil moisture content (gravimetric) during upland season of growing wheatafter three-cropping cycles.

\begin{tabular}{|c|c|c|c|c|c|}
\hline \multirow{2}{*}{ Treatment } & \multicolumn{5}{|c|}{ Soil moisture content (\%) } \\
\hline & Initial & 18 DAS & 55 DAS & 75 DAS & At harvest \\
\hline \multicolumn{6}{|c|}{ Tillage practices } \\
\hline MT & 15.45 & 15.79 & 14.58 & 15.76 & 21.52 \\
\hline $\mathrm{CT}$ & 13.78 & 13.35 & 12.43 & 13.75 & 18.53 \\
\hline DT & 13.75 & 13.99 & 12.28 & 13.81 & 18.41 \\
\hline $\mathrm{SE}( \pm)$ & 0.19 & 0.34 & 0.41 & 0.37 & 0.18 \\
\hline Probability & NS & NS & NS & NS & NS \\
\hline \multicolumn{6}{|c|}{ Previous crop residue retention } \\
\hline So & $12.39 \mathrm{f}$ & $12.27 \mathrm{~d}$ & $12.09 \mathrm{e}$ & $11.77 \mathrm{~d}$ & $15.72 \mathrm{~d}$ \\
\hline $\mathrm{Sr}$ & $13.26 \mathrm{e}$ & $12.93 \mathrm{c}$ & $12.81 \mathrm{~d}$ & $12.41 \mathrm{c}$ & $17.18 \mathrm{c}$ \\
\hline $\mathrm{Sm}$ & $13.46 \mathrm{de}$ & $13.12 \mathrm{c}$ & $12.99 \mathrm{~cd}$ & $12.46 \mathrm{bc}$ & $17.23 \mathrm{c}$ \\
\hline SW & $13.49 \mathrm{~d}$ & $13.15 \mathrm{c}$ & $13.31 \mathrm{c}$ & $12.42 \mathrm{c}$ & $18.16 \mathrm{bc}$ \\
\hline Smr & $14.30 \mathrm{bc}$ & $13.70 \mathrm{~b}$ & $13.89 \mathrm{~b}$ & $13.12 \mathrm{~b}$ & $18.91 \mathrm{~b}$ \\
\hline Srw & $14.26 \mathrm{c}$ & $13.62 \mathrm{~b}$ & $13.77 \mathrm{~b}$ & $13.10 \mathrm{~b}$ & $18.82 \mathrm{~b}$ \\
\hline Smw & $14.50 \mathrm{~b}$ & $13.72 \mathrm{~b}$ & $13.93 \mathrm{~b}$ & $13.51 \mathrm{~b}$ & $19.94 \mathrm{~b}$ \\
\hline Swrm & $15.21 \mathrm{a}$ & $14.51 \mathrm{a}$ & $14.64 \mathrm{a}$ & $14.30 \mathrm{a}$ & $20.57 \mathrm{a}$ \\
\hline $\mathrm{SE}( \pm)$ & 0.11 & 0.16 & 0.18 & 0.18 & 0.12 \\
\hline Probability & $* *$ & $* *$ & $* *$ & ** & $* *$ \\
\hline CV (\%) & 6.01 & 7.05 & 8.27 & 7.62 & 6.38 \\
\hline
\end{tabular}

Means followed by common letter in the same column are not significantly different at $5 \%$ level by DMRT. Notes: $S_{0}-$ no crop residues retention, $S_{r}-$ retention of $30 \mathrm{~cm}$ rice straw, $S_{m}-$ retention of whole mungbeanstover, $S_{w}-$ retention of $30 \mathrm{~cm}$ wheat straw, $S_{m r}$-retention of whole mungbeanstover \& $30 \mathrm{~cm}$ rice straw, $\mathrm{S}_{\mathrm{rw}}-$ retention of $30 \mathrm{~cm}$ rice \& wheat straw), $\mathrm{S}_{\mathrm{mw}}-$ retention of whole mungbeanstover \& $30 \mathrm{~cm}$ wheat straw and $S_{w r m}$-retention of $30 \mathrm{~cm}$ wheat and rice straw along with whole mungbeanstover, SEStandard error, CV-Co-efficient of variance; NS-Not significant, ${ }^{* *}-$ Significant at $1 \%$ probability level, DAS $=$ Days after sowing.

The soil moisture content increased at all sampling dates $(\mathrm{p}<0.05)$ from initial to crop harvest due to previous crop residue retention after 3-cropping cycles under wheat-mungbean-rice cropping system (Table 5). The highest soil moisture content was found in $S_{w r m}$ treated plots where all three crop residues were retained followed by two crop residues retained plots and single crop residue retained plots, whereas the lowest values were obtained in $\mathrm{S}_{0}$ plots where no crop residue was retained (Table 5).

\subsection{Effects of Tillage Practices on Crop Yields}

\subsubsection{In first Crop Cycle}

In the first cropping year (2009-2010), wheat yield was influenced by different tillage practices $(\mathrm{p}<0.05)$. The highest yield $(4.63$ and $5.35 \mathrm{t} / \mathrm{ha}$ of grain and straw, respectively) was attained in DT, whereas the lowest $3.95 \mathrm{t} / \mathrm{ha}$ grain and $4.45 \mathrm{t} / \mathrm{ha}$ straw was in MT (Table 6). 
Table 6. Effects of tillage practices and previous crop residue retention on the crop yields over time.

\begin{tabular}{|c|c|c|c|c|c|c|c|c|c|c|c|c|c|c|c|c|c|c|}
\hline \multirow{3}{*}{ Treatment } & \multicolumn{2}{|c|}{ Wheat } & \multicolumn{2}{|c|}{ Mungbean } & \multicolumn{2}{|c|}{ Rice } & \multicolumn{2}{|c|}{ Wheat } & \multicolumn{2}{|c|}{ Mungbean } & \multicolumn{2}{|c|}{ Rice } & \multicolumn{2}{|c|}{ Wheat } & \multicolumn{2}{|c|}{ Mungbean } & \multicolumn{2}{|c|}{ Rice } \\
\hline & \multicolumn{2}{|c|}{ 2009-2010 } & \multicolumn{2}{|c|}{2010} & \multicolumn{2}{|c|}{2010} & \multicolumn{2}{|c|}{$2010-2011$} & \multicolumn{2}{|c|}{2011} & \multicolumn{2}{|c|}{2011} & \multicolumn{2}{|c|}{ 2011-2012 } & \multicolumn{2}{|c|}{2012} & \multicolumn{2}{|c|}{2012} \\
\hline & $\begin{array}{l}\text { Grain } \\
\text { yield } \\
\text { (t/ha) }\end{array}$ & $\begin{array}{l}\text { Straw } \\
\text { Yield } \\
\text { (t/ha) }\end{array}$ & $\begin{array}{l}\text { Grain } \\
\text { Yield } \\
(\mathrm{t} / \mathrm{ha})\end{array}$ & $\begin{array}{l}\text { Straw } \\
\text { Yield } \\
(\mathrm{t} / \mathrm{ha})\end{array}$ & $\begin{array}{l}\text { Grain } \\
\text { Yield } \\
(\mathrm{t} / \mathrm{ha})\end{array}$ & $\begin{array}{l}\text { Straw } \\
\text { Yield } \\
(\mathrm{t} / \mathrm{ha})\end{array}$ & $\begin{array}{l}\text { Grain } \\
\text { Yield } \\
\text { (t/ha) }\end{array}$ & $\begin{array}{l}\text { Straw } \\
\text { Yield } \\
(\mathrm{t} / \mathrm{ha})\end{array}$ & $\begin{array}{l}\text { Grain } \\
\text { Yield } \\
(\mathrm{t} / \mathrm{ha})\end{array}$ & $\begin{array}{l}\text { Straw } \\
\text { Yield } \\
(\mathrm{t} / \mathrm{ha})\end{array}$ & $\begin{array}{l}\text { Grain } \\
\text { Yield } \\
\text { (t/ha) }\end{array}$ & $\begin{array}{l}\text { Straw } \\
\text { Yield } \\
\text { (t/ha) }\end{array}$ & $\begin{array}{l}\text { Grain } \\
\text { Yield } \\
(\mathrm{t} / \mathrm{ha})\end{array}$ & $\begin{array}{l}\text { Straw } \\
\text { Yield } \\
(\mathrm{t} / \mathrm{ha})\end{array}$ & $\begin{array}{l}\text { Grain } \\
\text { Yield } \\
\text { (t/ha) }\end{array}$ & $\begin{array}{l}\text { Straw } \\
\text { Yield } \\
\text { (t/ha) }\end{array}$ & $\begin{array}{l}\text { Grain } \\
\text { Yield } \\
(\mathrm{t} / \mathrm{ha})\end{array}$ & $\begin{array}{l}\text { Straw } \\
\text { Yield } \\
(\mathrm{t} / \mathrm{ha})\end{array}$ \\
\hline \multicolumn{19}{|c|}{ Tillage practices } \\
\hline MT & $3.95 \mathrm{~b}$ & $4.45 \mathrm{~b}$ & 0.96 & 8.05 & 4.08 & 5.00 & 4.11 & 4.56 & 0.99 & 8.25 & 4.21 & 5.21 & $3.99 \mathrm{a}$ & 4.44 & 0.99 & 8.12 & 4.19 & 5.16 \\
\hline CT & $4.51 \mathrm{a}$ & $5.15 \mathrm{a}$ & 0.97 & 8.23 & 4.30 & 5.17 & 3.83 & 4.7 & 0.99 & 8.39 & 4.30 & 5.26 & $3.77 \mathrm{~b}$ & 4.72 & 0.99 & 8.40 & 4.39 & 5.26 \\
\hline DT & $4.63 \mathrm{a}$ & $5.35 \mathrm{a}$ & 0.97 & 8.36 & 4.26 & 5.22 & 3.81 & 4.77 & 0.98 & 8.5 & 4.36 & 5.3 & $3.56 \mathrm{c}$ & 4.87 & 0.98 & 8.63 & 4.33 & 5.34 \\
\hline $\mathrm{SE}( \pm)$ & 0.092 & 0.128 & 0.22 & 0.102 & 0.05 & 0.11 & 0.065 & 0.15 & 0.34 & 0.13 & 0.09 & 0.09 & 0.041 & 0.095 & 0.47 & 0.12 & 0.12 & 0.12 \\
\hline Probability & * & * & NS & NS & NS & NS & * & NS & NS & NS & NS & NS & ** & NS & NS & NS & NS & NS \\
\hline \multicolumn{19}{|c|}{ Previous crop residue retention } \\
\hline $\mathrm{S}_{0}$ & - & - & 0.96 & 8.09 & $3.60 \mathrm{e}$ & $4.32 \mathrm{e}$ & 3.12 & 4.38 & 0.79 & 7.82 & $3.84 \mathrm{e}$ & $4.08 \mathrm{~d}$ & $2.47 \mathrm{e}$ & $4.08 \mathrm{~g}$ & 0.97 & 8.26 & $3.97 \mathrm{e}$ & $4.91 \mathrm{~d}$ \\
\hline $\mathrm{S}_{\mathrm{r}}$ & - & - & 0.96 & 8.16 & $3.89 \mathrm{~d}$ & $4.88 \mathrm{c}$ & 3.57 & 4.5 & 0.94 & 8.14 & $3.85 \mathrm{~d}$ & $4.38 \mathrm{bc}$ & $3.36 \mathrm{~d}$ & $4.33 \mathrm{f}$ & 0.98 & 8.30 & 4.11 cde & $5.11 \mathrm{~cd}$ \\
\hline $\mathrm{S}_{\mathrm{m}}$ & - & - & 0.96 & 8.18 & $4.01 \mathrm{~d}$ & $4.92 \mathrm{c}$ & 3.54 & 4.61 & 0.95 & 8.46 & $4.25 \mathrm{bc}$ & $4.42 \mathrm{bc}$ & $3.31 \mathrm{~d}$ & $4.55 \mathrm{e}$ & 0.98 & 8.33 & $4.19 \mathrm{~b}-\mathrm{e}$ & $5.14 \mathrm{~cd}$ \\
\hline $\mathrm{S}_{\mathrm{W}}$ & - & - & 0.96 & 8.13 & $3.72 \mathrm{e}$ & $4.80 \mathrm{~d}$ & 3.49 & 4.64 & 0.95 & 8.44 & $4.08 \mathrm{c}$ & $4.24 \mathrm{c}$ & $3.21 \mathrm{~d}$ & $4.61 \mathrm{de}$ & 0.99 & 8.36 & $4.01 \mathrm{de}$ & $5.03 \mathrm{~d}$ \\
\hline $\mathrm{S}_{\mathrm{mr}}$ & - & - & 0.97 & 8.22 & $4.30 \mathrm{c}$ & $5.46 \mathrm{~b}$ & 4.04 & 4.71 & 0.95 & 8.35 & $4.31 \mathrm{bc}$ & $4.64 \mathrm{bc}$ & $\begin{array}{c}4.31 \\
b c\end{array}$ & $4.74 \mathrm{~cd}$ & 0.99 & 8.38 & $4.31 \mathrm{bc}$ & $5.42 \mathrm{ab}$ \\
\hline $\mathrm{S}_{\mathrm{rw}}$ & - & - & 0.97 & 8.20 & $4.24 \mathrm{c}$ & $5.39 \mathrm{c}$ & 3.99 & 4.75 & 0.95 & 8.43 & $4.29 \mathrm{bc}$ & $4.91 \mathrm{~b}$ & $4.20 \mathrm{c}$ & $4.83 \mathrm{bc}$ & 0.99 & 8.41 & $4.27 \mathrm{bcd}$ & $5.31 \mathrm{bc}$ \\
\hline $\mathrm{S}_{\mathrm{mw}}$ & - & - & 0.97 & 8.26 & $4.52 \mathrm{~b}$ & $5.80 \mathrm{a}$ & 4.13 & 4.82 & 0.99 & 8.4 & $4.55 \mathrm{~b}$ & $5.38 \mathrm{a}$ & $4.48 \mathrm{~b}$ & $4.97 \mathrm{~b}$ & 0.99 & 8.44 & $4.40 \mathrm{~b}$ & $5.51 \mathrm{ab}$ \\
\hline$S_{\text {wrm }}$ & - & - & 0.97 & 8.28 & $5.20 \mathrm{a}$ & $5.85 \mathrm{a}$ & 4.32 & 5.00 & 1.08 & 8.64 & $4.78 \mathrm{a}$ & $5.51 \mathrm{a}$ & $4.86 \mathrm{a}$ & $5.32 \mathrm{a}$ & 1.00 & 8.49 & $4.66 \mathrm{a}$ & $5.57 \mathrm{a}$ \\
\hline $\mathrm{SE}( \pm)$ & - & - & 0.15 & 0.137 & 0.047 & 0.089 & 0.10 & 0.06 & 0.41 & 0.21 & 0.07 & 0.09 & 0.09 & 0.058 & 0.39 & 0.13 & 0.08 & 0.08 \\
\hline Probability & - & - & NS & NS & $* *$ & $* *$ & NS & NS & NS & NS & $* *$ & $* *$ & $* *$ & $* *$ & NS & NS & $* *$ & $* *$ \\
\hline CV (\%) & 2.48 & 5.12 & 4.54 & 5.02 & 3.34 & 5.14 & 4.56 & 4.37 & 6.4 & 5.83 & 6.42 & 7.43 & 5.06 & 3.71 & 11.17 & 4.75 & 3.34 & 5.14 \\
\hline
\end{tabular}

Means followed by common letter(s) in the same column are not significantly different at $5 \%$ level by DMRT. Notes: $\mathrm{S}_{0}-$ no crop residues retention, $\mathrm{S}_{\mathrm{r}}-$ retention of $30 \mathrm{~cm}$ rice straw, $\mathrm{S}_{\mathrm{m}}$-retention of whole mungbeanstover, $\mathrm{S}_{\mathrm{w}}-$ retention of $30 \mathrm{~cm}$ wheat straw, $\mathrm{S}_{\mathrm{mr}}-$ retention of whole mungbeanstover \& $30 \mathrm{~cm}$ rice straw, $\mathrm{S}_{\mathrm{rw}}-$ retention of $30 \mathrm{~cm}$ rice \& wheat straw), $\mathrm{S}_{\mathrm{mw}}-$ retention of whole mungbeanstover $\& 30 \mathrm{~cm}$ wheat straw and $\mathrm{S}_{\mathrm{wrm}}-$ retention of $30 \mathrm{~cm}$ wheat and rice straw along with whole mungbeanstover, $\mathrm{S}_{\mathrm{E}}-$ Standard error, $\mathrm{CV}-\mathrm{Co}$-efficient of variance; NS-Not significant, *, ** Significant at 5 and $1 \%$ probability level, respectively.

In case of second crop (mungbean), there was no significant variation among the tillage practices on grain and stover yield (Table 6). However, the highest grain $(0.97 \mathrm{t} / \mathrm{ha})$ and stover $(8.36 \mathrm{t} / \mathrm{ha})$ was found in CT and DT, respectively, whereas the lowest values were in MT practice.

In case of third crop (transplanted rice), grain and straw yield did not vary $(p>0.05)$ among the tillage practices. However, the highest grain $(4.30 \mathrm{t} / \mathrm{ha})$ and stover (5.22 t/ha) was found in CT and DT, respectively, whereas the lowest values were in MT practice (Table 6).

\subsubsection{In Second Crop Cycle}

Like first crop cycle, the yields of wheat varied due to tillage practices ( $\mathrm{p}<$ $0.05)$. But yield of all the crops showed increasing trend ( $p$ > 0.05) under MT 
(Table 6).

\subsubsection{In Third Crop Cycle}

In the third cropping year (2011-2012), grain yield of wheat varied due to tillage practices $(\mathrm{p}<0.05)$ and the highest $3.99 \mathrm{t} / \mathrm{ha}$ grain was obtained from MT practice which was statistically different from other two tillage practices, whereas the lowest grain was from DT practice. The CT practice gave the intermediate grain yield between MT and DT practice (Table 6).

In case of mungbean, there was no significant variation among the tillage practices on grain and stover yield but the MT (0.99 t/ha) and DT (8.63 t/ha) gave the highest grain and stover, respectively, whereas the lowest values were in DT practice.

The grain and straw yields of rice were not influenced by tillage practices $(p>$ $0.05)$ like first cropping year. However, the highest grain yield (4.39 t/ha) was attained in CT and the lowest yield (4.19 t/ha) was found in MT as presented in Table 4. CT and DT showed higher yield of rice (Table 6).

\subsection{Effects of Previous Crop Residue Retention on Crop Yields}

\subsubsection{In First Crop Cycle}

The effect of previous wheat crop residue retention on grain and stover yield of mungbean was not significant. But crop residue retention showed significant influence on third crop, rice yield. The highest grain (5.20 t/ha) and straw yield (5.85 $\mathrm{t} / \mathrm{ha}$ ) was found in $\mathrm{S}_{\mathrm{wrm}}$ where all three crop residue was retained and the lowest grain $(3.60 \mathrm{t} / \mathrm{ha})$ and straw yield $(4.32 \mathrm{t} / \mathrm{ha})$ was recorded in $\mathrm{S}_{0}$ where no crop residue was retained (Table 6).

\subsubsection{In Second Crop Cycle}

Similar to the first cropping cycle, the yields of mungbean $(\mathrm{p}>0.05)$ and wheat $(\mathrm{p}>0.05)$ did not vary due to residue retention practices, whereas the yield of $\mathrm{T}$ aman rice varied $(\mathrm{p}<0.05)$. But yield of all the crops showed increasing trend $(p>0.05)$ under increased residue retained treatment (Table 6).

\subsubsection{In Third Crop Cycle}

In the third cropping year $(2011-2012)$, grain yield of wheat varied $(\mathrm{p}<0.05)$ due to previous crop residue retention and the highest 4.86 and $5.32 \mathrm{t} / \mathrm{ha}$ of grain and straw was obtained from $S_{w r m}$ where residues of all the crops residue retained which was statistically different from all other crop residue retentions and the lowest grain and straw was from $\mathrm{S}_{0}$ where no crop residue retained ( $\mathrm{Ta}$ ble 6).

The effect of previous wheat crop residue retention on grain and stover yield of mungbean was not significant ( $\mathrm{p}>0.05$; Table 6).

Therice yield was influenced $(\mathrm{p}<0.05)$ by the crop residue retention. The highest $4.66 \mathrm{t} / \mathrm{ha}$ of grain was obtained from $S_{\mathrm{wrm}}$ where residues of the entire crops residue retained which was statistically different from all other crop residue retentions and lowest grain was from $S_{0}$ where no crop residue retained (Table 6). 


\section{Discussion}

\subsection{Effects of Tillage Practice and Crop Residue Retention on Physical Properties of Soil}

Insignificant variation in $\mathrm{BD}, \mathrm{PD}$ and porosity was found due to different tillage practices $(p>0.05)$ after three cropping cycles (Table 2$)$. Though tillage effects were insignificant in soil physical properties, BD was lower with MT and CT by $3 \%$ and $1 \%$ than with DT, respectively. PD with MT and CT were $3 \%$ and $0.5 \%$ lower than PD with DT, respectively. But porosity was recorded $1 \%$ higher with DT than MT and CT (Table 3). The present results are in agreement with the findings of Carefoot et al. [25] who observed that BD did not differ between MT and CT. The works of Jabro et al. [26] did not show any variations in PD among different tillage practices, whereas Cogle et al. [27] found insignificant increase in soil porosity as influenced by DT.

The soil physical properties also remained unchanged due to previous crop residue retention after 3-cropping cycles $(p>0.05)$ under the wheat-mungbeanrice cropping system (Table 3$)$. However, the lowest $\mathrm{BD}\left(1.38 \mathrm{~g} / \mathrm{cm}^{3}\right)$ was found in $\mathrm{S}_{\text {wrm }}$ which was $4 \%$ lower than $\mathrm{S}_{0}$ where the highest $\mathrm{BD}\left(1.44 \mathrm{~g} / \mathrm{cm}^{3}\right)$ was recorded (Table 3). The lowest PD as found with $\mathrm{S}_{\mathrm{wrm}}$ was $2.5 \%$ lower than PD as found with $\mathrm{S}_{0}$. Soil porosity were also invariably $(\mathrm{p}>0.05)$ changed due to crop residue retention (Table 3 ). The highest porosity recorded with $\mathrm{S}_{\mathrm{wrm}}$ was $2.5 \%$ higher than the lowest porosity with $S_{0}$. Sidhu and Sur [28] reported that residue retention/incorporation insignificantly lowered the soil $\mathrm{BD}$ which is in agreement with the findings of our study. Lipiec et al. [29] found insignificant variations in porosity for a short-term experimentation with residue retention.

\subsection{Effects of Tillage Practices and Crop Residue Retention on SOC Content}

Interactive effect of tillage practices and crop residue retention influenced $(\mathrm{p}<$ 0.05) SOC after nine crops in sequence (Table 4). The significantly highest SOC content was found due to the combined effect of MT and retention of three crop residues $\left(\mathrm{MT} \times \mathrm{S}_{\mathrm{wrm}}\right.$ ) which was around $200 \%$ higher than SOC under DT with no crop residues retention $\left(D T \times S_{0}\right.$ ). The SOC under MT $\times S_{\text {wrm }}$ was statistically different from all other treatment combinations. Baker et al. [30] and D' haene et al. [31] showed that more SOC under MT or no tillage in comparison to extensive tillage. Naresh et al. [32] reported that the combination of reduced tillage with crop residue retention increases the SOC in the top soil.

\subsection{Effects of Tillage Practices and Crop Residue Retention on Soil Moisture}

The soil moisture did not change $(\mathrm{p}>0.05)$ significantly due to different tillage practices and decreased gradually over the time (Table 5). Soil moisture contents under MT were 12,13,18, 14 and 17\% higher than moisture content in DT at pre-sowing, 18, 25, 75 DAS and at harvest, respectively. On the other hand, the moisture content increased at all sampling dates $(\mathrm{p}<0.05)$ from initial to 
crop harvest due to previous crop residue retention after 3-cropping cycles ( $\mathrm{Ta}$ ble 5). The moisture content in $S_{w r m}$ treated plots where all three crop residues were retained were $23,19,21,22$ and $31 \%$ higher than moisture content in $\mathrm{S}_{0}$ plots where no crop residue was retained (Table 5). After 3-cropping cycles, more than $36 \mathrm{t} / \mathrm{ha}$ of total crop residues (12 t/ha/yr of which wheat $\sim 1.6 \mathrm{t} / \mathrm{ha}$, rice $\sim 2.0 \mathrm{t} / \mathrm{ha}$ and mungbean $\sim 8.5 \mathrm{t} / \mathrm{ha}$ ) were retained in $\mathrm{S}_{\text {wrm }}$ treatment which resulted in increase of soil OM, thus conserved more moisture. Hartwig \& Ammon [33] stated that when cover crop residues left on the surface, conserve soil moisture by reducing evaporation. Results obtained from the works of Rahman et al. [34] showed that rice straw mulching had a significant effect on moisture conservation in MT or no-till wheat fields.

\subsection{Effects of Tillage Practices on Crop yields}

\subsubsection{In First Crop Cycle}

In the first cropping year (2009-2010), a significant variation in wheat yield was found due to tillage practices $(\mathrm{p}<0.05)$. The highest yields at tained in DT were $17 \%$ and $20 \%$ higher than grain and straw yields in MT and 14 and $16 \%$ higher than grain and straw yields in CT, respectively (Table 6). Mungbean and rice yield had insignificant variation among the tillage. However, the highest grain and stover/straw yields were found in CT and DT, respectively, whereas the lowest values were in MT practice. Similar trend was observed in case of third crop, rice.

\subsubsection{In Second Crop Cycle}

Yields of all crops showed increasing trend under minimum tillage practice in the second year of cropping system continuation [15].

\subsubsection{In Third Crop Cycle}

In the third cropping year (2011-2012), grain yield of wheat varied due to tillage practices $(\mathrm{p}<0.05)$ but a reverse trend was found i.e., the highest $(3.99 \mathrm{t} / \mathrm{ha})$ grain was obtained from MT practice and the lowest grain (3.56 t/ha) was from DT practice. This might be due to after 3-crop cycle, a considerable amount of OM accumulated under MT practices, therefore, there was no chance to form the plough pan and produced good soil condition for plant growth and resulted in higher yield. In contrast, the CT and DT practices created a hard plough pan below the soil surface layer during puddling which retarded root penetration and proliferation that had adverse effects on crop yield [35]. The grain and straw yields of rice did not vary among tillage practices $(\mathrm{p}>0.05)$ like first cropping year. However, the highest rice grain yield in DT was $4.5 \%$ higher than MT (Table 4). CT and DT showed higher yield of rice and this might be due to more water conserved under these two tillage practices for puddling before seedling transplanting. It was observed that the deep and minimum tillage practice consistently produced the highest and the lowest yields of straw/stover for each component crop, respectively.

It was also noticed that MT performed better in dry land crops (wheat and 
mungbean), whereas performances of wetland crop (transplanted rice) were better under deep and conventional tillage. Singh \& Kaur [4] and Millar et al. [36] stated that the yield of crop under MT may be equivalent or somewhat lower than CT, but MT had lower cultivation costs, due to less passes required to create a satisfactory seedbed with a machine, save time, labour and fuel and ensure sowing of crops earlier than conventional tillage, therefore MT gets preference.

\subsection{Effects of Previous Crop Residue Retention on Crop Yields}

\subsubsection{In First Crop Cycle}

Wheat crop residue retained during mungbean growing season did not vary grain and stover yield of mungbean $(\mathrm{p}>0.05)$. But, residue retention showed influence $(\mathrm{p}<0.05)$ on subsequent rice yield. The grain and straw yields in $\mathrm{S}_{\mathrm{wrm}}$ were $44 \%$ and $35 \%$ higher than rice grain and straw yields in $S_{0}$, whereas $26 \%$ and $34 \%$ higher grain and straw yields with $\mathrm{S}_{\mathrm{mw}}$ than yields in $\mathrm{S}_{0}$, respectively. The grain and straw yields under $S_{w r m}$ and $S_{m w}$ were followed by $S_{m r}, S_{r w}, S_{m}, S_{r}$, $S_{\mathrm{W}}$ treatments. The lowest grain and straw yields were recorded in $S_{0}$ where no crop residue was retained (Table 6).

\subsubsection{In Second Crop Cycle}

Yields of all crops showed increasing trend under increased residue retentions in the second year of cropping system continuation [37].

\subsubsection{In Third Crop Cycle}

In the third cropping year (2011-2012), grain yield of wheat significantly varied due to previous crop residue retention. The highest grain and straw yields obtained from $\mathrm{S}_{\mathrm{wrm}}$ were $97 \%$ and $30 \%$ higher than yields under $\mathrm{S}_{0}$, respectively. The grain and straw yields in $\mathrm{S}_{\mathrm{mw}}$ were $81 \%$ and $22 \%$ higher than yields in $\mathrm{S}_{0}$, respectively. Residue retention effect on mungbean biomass and grain yields was not significant $(\mathrm{p}>0.05)$ but the effect was significant on rice yields $(\mathrm{p}<0.05)$. The grain yields of rice in $\mathrm{S}_{\mathrm{wrm}}$ and $\mathrm{S}_{\mathrm{mw}}$ were $17 \%$ and $11 \%$ higher than yields in $\mathrm{S}_{0}$. Rice straw yields were similar in trends of grain yields (Table 6). Rice grain and straw showed significant differences due to the crop residue retention and followed the sequence: $\mathrm{S}_{\mathrm{wrm}}>\mathrm{S}_{\mathrm{mw}}>\mathrm{S}_{\mathrm{mr}}>\mathrm{S}_{\mathrm{rw}}>\mathrm{S}_{\mathrm{m}}>\mathrm{S}_{\mathrm{r}}>\mathrm{S}_{\mathrm{W}}>\mathrm{S}_{0}$. Singh \& Singh [38] reported that incorporation of mungbean residue after picking pods, significantly increased rice yield in rice-wheat system. This result is also consistent with the findings of Wilhelm et al. [39] who reported that grain and biomass yield of the current crop was increased with incorporation of previous crop's residue.

\section{Conclusion}

The SOC and moisture content were significantly increased in minimum tillage with three crop residue retention than all other treatment combinations, while the soil physical properties remained unchanged due to tillage-residue retention practices under the wheat-mungbean-rice cropping system. From 3-cropping 
cycle, it was also summarized that minimum tillage practice performed better in dry land crops (wheat \& mungbean) and conventional tillage out-performed in case of low land crop, rice.

\section{Acknowledgements}

The authors gratefully thank to laboratories of Soil Science Division of Bangladesh Agricultural Research Institute (BARI), Bangladesh and to BARC (Bangladesh Agricultural Research Council) for their advices.

\section{References}

[1] Alam, M.K., Biswas, W.K. and Bell, R.W. (2016) Greenhouse Gas Implications of Novel and Conventional Rice Production Technologies in the Eastern-Gangetic Plains. Journal of Cleaner Production, 112, 3977-3987.

https://doi.org/10.1016/j.jclepro.2015.09.071

[2] Alam, M.K., Islam, M.M., Salahin, N. and Hasanuzzaman, M. (2014) Effect of Tillage Practices on Soil Properties and Crop Productivity in Wheat-Mungbean-Rice Cropping System under Subtropical Climatic Conditions. The Scientific World Journal, 2014, 1-10. https://doi.org/10.1155/2014/437283

[3] Busscher, W.J. and Bauer, P.J. (2004) Soil Strength, Cotton Root Growth and Lint Yield in a Southeastern USA Coastal Loamy Sand. Soil \& Tillage Research, 74, 151159. https://doi.org/10.1016/j.still.2003.06.002

[4] Singh, A. and Kaur, J. (2012) Impact of Conservation Tillage on Soil Properties in Rice-Wheat Cropping System. Agricultural Science Research Journal, 2, 30-41.

[5] Weil, R.R. (1992) Inside the Heart of Sustainable Farming. The New Farm, 43-48.

[6] BARC (2012) Fertilizer Recommendation Guide (FRG). Bangladesh Agricultural Research Council, Dhaka.

[7] Azraf-Ul-Haq, A., Imran, Q. and Naeem, M. (2007) Effect of Integrateduse of Irganic and Inorganic Fertilisers on Fodder Yield of Sorghum (Sorghum bicolor L). Pakistan Journal of Plant Sciences, 27, 322-329.

[8] Mandal, K.G., Misra, A.K., Hati, K.M., Bandyopadhyay, K.K., Ghosh, P.K. and Mohanty, M. (2004) Rice Residue-Management Options and Effects on Soil Properties and Crop Productivity. Food, Agriculture and Environment, 2, 224-231.

[9] Rijpma, J. and Jahiruddin, M. (2004) National Strategy and Plan for Use of Soil Nutrient Balance in Bangladesh. A Consultancy Report. SFFP, Khamarbari, Dhaka.

[10] Singh, Y. and Sidhu, H.S. (2014) Management of Cereal Crop Residues for Sustainable Rice-Wheat Production System in the Indo-Gangetic Plains of India. Proceedings of the National Academy of Sciences, 80, 95-114. https://doi.org/10.16943/ptinsa/2014/v80i1/55089

[11] Yadav, R.L. and Verma, R.P. (1995) Crop Residue Management to Conserve Soil Organic Matter Content in Sugarcane-Based Crop Rotations. Bioresource Technology, 51, 241-245. https://doi.org/10.1016/0960-8524(94)00135-N

[12] Conceição, P.C., Amado, T.J.C., Mielniczuk, J. and Spagnollo, E. (2005) Qualidade do solo em sistemas de manejo avaliada pela dinâmica da matéria orgânica e atributos relacionados. Revista Brasileira de Ciência do Solo, 29, 777-788. https://doi.org/10.1590/S0100-06832005000500013

[13] Bayer, C., Dieckow, J., Amado, T.J.C., Eltz, F.L.F. and Vieira, F.C.B. (2009) Cover Crop Effects Increasing Carbon Storage in a Subtropical No-Till Sandy Acrisol. Communications in Soil Science and Plant Analysis, 40, 1499-1511. 
https://doi.org/10.1080/00103620902820365

[14] Kushwaha, C.P., Tripathi, S.K. and Singh, K.P. (2001) Soil Organic Matter and Water-Stable Aggregates under Different Tillage and Residue Conditions in a Tropical Dry Land Agro-Ecosystem. Applied Soil Ecology, 16, 229-241. https://doi.org/10.1016/S0929-1393(00)00121-9

[15] Alam, M.K., Salahin, N., Islam, S., Begum, R.A., Hasanuzzaman, M., Islam, M.S. and Rahman, M.M. (2016) Patterns of Change in Soil Organic Matter, Physical Properties and Crop Productivity under Tillage Practices and Cropping Systems in Bangladesh. The Journal of Agricultural Science, 1-23. https://doi.org/10.1017/S0021859616000265

[16] Bari, M.N. and Islam, M. (2009) Selection of Mungbean Variety for Rice-WheatFallow Cropping System-A Participatory Research and Development (PR\&D) Approach. Journal Agriculture and Rural Development, 7, 33-40.

[17] Davari, M.R., Sharma, S.N. and Mirzakhani, M. (2012) Effect of Cropping Systems and Crop Residue Incorporation on Production and Properties of Soil in an Organic Agro-Ecosystem. Biological Agriculture \& Horticulture: An International Journal for Sustainable Production Systems, 28, 206-222. https://doi.org/10.1080/01448765.2012.735005

[18] Ghosh, P. (1983) Institute of Agriculture, Visva-Bharati, Srinike Tan-731-236. West Bengal, India. Indian Journal of Agricultural Research, 32, 75-80.

[19] Jackson, M.L. (1973) Soil Chemical Analysis. Prentice Hall of India Pvt. Ltd., New Delhi.

[20] Page, A.L., Miller, R.H. and Kuny, D.R. (1989) Methods of Soil Analysis. Part 2. 2nd Edition, American Society of Agronomy, Soil Science Society America, Madison.

[21] Bouyoucos, G.J. (1962) Hydrometer Method Improved for Making Particle Size Analysis of Soils. Agronomy Journal, 54, 464-465. https://doi.org/10.2134/agronj1962.00021962005400050028x

[22] Karim, Z., Rahman, S.M., Ali, M.I. and Karim, A.J.M.S. (1988) Soil Bulk Density. A Manual for Determination of Soil Physical Parameters. Soils and Irrigation Division, BARC, Dhaka.

[23] Black, C.A. (1965) Methods of Soil Analysis: Part I Physical and Mineralogical Properties. American Society of Agronomy, Madison.

[24] Steel, R.C.B. and Torrie, J.H. (1960) Principles and Procedures of Statistics. McGraw Hall, New York.

[25] Carefoot, J.M., Nyborg, M. and Lindwall, C.W. (1990) Tillage-Induced Soil Changes and Related Grain Yield in a Semi-Arid Region. Canadian Journal of Soil Science, 73, 203-214. https://doi.org/10.4141/cjss90-022

[26] Jabro, J.D., Sainju, U.M., Stevens, W.B., Lenssen, A.W. and Evans, R.G. (2008) Long-Term Tillage Frequency Effects on Dry Land Soil Physical and Hydraulic Properties. Proceeding of the International Soil Conservation Organization Conference, Budapest, 15-23 May 2008.

[27] Cogle, A.L., Rao, K.P.C., Yule, D.F., George, P.J., Srinivasan, S.T., Smith, G.D. and Jangawad, L. (1997) Soil Management Options for Alfisol in the Semi-Arid Tropics: Annual and Perennial Crop Production. Soil \& Tillage Research, 44, 235-253. https://doi.org/10.1016/S0167-1987(97)00057-3

[28] Sidhu, A.S. and Sur, H.S. (1993) Effect of Incorporation of Legume Straw on Soil Properties and Crop Yield in a Maize-Wheat Sequence. Tropical Agriculture, 70, 226-229.

[29] Lipiec, J., Kus, J., Slowinska-Jurkiewicz, A. and Nosalewicz, A. (2006) Soil Porosity 
and Water Infiltration as Influenced by Tillage Methods. Soil \& Tillage Research, 89, 210-220. https://doi.org/10.1016/j.still.2005.07.012

[30] Baker, J.M., Ochsner, T.E., Venterea, R.T. and Griffis, T.J. (2007) Tillage and Soil Carbon Sequestration-What Do We Really Know? Agriculture Ecosystem Environment, 118, 1-5. https://doi.org/10.1016/j.agee.2006.05.014

[31] D’haene, K., Sleutel, S., DeNeve, S., Gabriels, D. and Hofman, G. (2009) The Effect of Reduced Tillage Agriculture on Carbon Dynamics in Silt Loam Soils. Nutrient Cycling in Agroecosystems, 84, 249-265. https://doi.org/10.1007/s10705-008-9240-9

[32] Naresh, R.K., Singh, S.P., Dwivedi, A., Sepat, N.K., Kumar, V., Ronaliya, L.K., Kumar, V. and Singh, R. (2013) Conservation Agriculture Improving Soil Quality for Sustainable Production Systems under Smallholder Farming Conditions in North West India: A Review. International Journal of Life Science, Botanical and Pharmaceutical Research, 2, 151-213.

[33] Hartwig, N.L. and Ammon, H.U. (2002) Cover Crops and Living Mulches. Weed Science, 50, 688-699. https://doi.org/10.1614/0043-1745(2002)050[0688:AIACCA]2.0.CO;2

[34] Rahman, M.A., Chikushi, J., Saifuzzman, M. and Lauren, J.G. (2005) Rice Straw Mulching and Nitrogen Response of No-Till Wheat Following Rice in Bangladesh. Field Crops Research, 91, 71-81. https://doi.org/10.1016/j.fcr.2004.06.010

[35] Khan, M.S., Rahman, M.M., Begum, R.A., Alam, M.K., Mondol, A.T.M.A.I., Islam, M.S. and Salahin, N. (2008) Research Experiences with Problem Soils of Bangladesh. Soil Science Division, Bangladesh Agricultural Research Institute (BARI), Joydebpur, 1-176.

[36] Millar, D., Beaton, D., Clark, B. and Bryson, R. (2001) Agriknowledge Guide. HGCA, London.

[37] Salahin, N., Jahiruddin, M., Islam, M.R., Bell, R.W., Haque, M.E. and Alam, M.K. (2014) Effects of Minimum Tillage Practices and Crop Residue Retention on Soil Properties and Crop Yields under a Rice-Based Cropping System. Proceedings of the Conference on Conservation Agriculture for Smallholders in Asia and Africa, Mymensingh, 7-11 December 2014, 133-134.

[38] Singh, Y. and Singh, B. (2001) Efficient Management of Primary Nutrition in the Rice-Wheat System. In: Kataki, P.K., Ed., The Rice-Wheat Cropping Systems of South Asia: Efficient Production Management, Food Products Press, New York, 23 85.

[39] Wilhelm, W.W., Doran, J.W. and Power, J.F. (1986) Corn and Soybean Yield Response to Crop Residue Management under No-Tillage Production Systems. Agronomy Journal, 78, 184-189.

https://doi.org/10.2134/agronj1986.00021962007800010036x

\footnotetext{
Abbreviations

BARC $=$ Bangladesh Agricultural Research Council,

BARI = Bangladesh Agricultural Research Institute,

BRRI $=$ Bangladesh Rice Research Institute,

SOC $=$ Soil Organic Carbon .
} 
Submit or recommend next manuscript to SCIRP and we will provide best service for you:

Accepting pre-submission inquiries through Email, Facebook, LinkedIn, Twitter, etc. A wide selection of journals (inclusive of 9 subjects, more than 200 journals)

Providing 24-hour high-quality service

User-friendly online submission system

Fair and swift peer-review system

Efficient typesetting and proofreading procedure

Display of the result of downloads and visits, as well as the number of cited articles Maximum dissemination of your research work

Submit your manuscript at: http://papersubmission.scirp.org/

Or contact ojss@scirp.org 